\title{
Aloe Vera and Cancer
}

\author{
Ahmet ÜNLÜ, ${ }^{1}$ Erdinç NAYIR, ${ }^{2}$ Hale AY, ${ }^{1}$ Önder KIRCA, ${ }^{3}$ Mustafa ÖZDOĞAN ${ }^{3}$ \\ ${ }^{1}$ Akdeniz University Faculty of Medicine, Antalya-Turkey \\ ${ }^{2}$ Department of Medical Oncology, Kahramanmaraş Necip Fazil City Hospital, Kahramanmaraş-Turkey \\ ${ }^{3}$ Department of Medical Oncology, Antalya Memorial Hospital, Antalya-Turkey
}

\begin{abstract}
SUMMARY
Aloe vera, a succulent plant species, has a long history in folk medicine. Its clear, viscous liquid has been used to treat skin problems and other disorders since ancient times. In the last century, oral consumption and the injection of aloe have also come to popular attention. Its topical use is effective in the treatment of burns and abrasions, and oral use is effective in the treatment of constipation. However, it has not been found to be superior to standard treatments. Most recently, claims of anti-cancer properties are prevalent. It has been found to inhibit proliferation and angiogenesis, and to induce apoptosis in cancer cells. Yet other clinical studies indicate that Aloe vera did not prevent or reduce the number of radiotherapy-related lesions; it merely delayed onset. Furthermore, many instances of toxicity and mortality have been reported in the literature. Today, it is better to avoid it, especially forms taken orally or by injection.
\end{abstract}

Keywords: Aloe barbadensis; Aloe capensis; Aloe vera; alternative medicine; cancer; phytotherapy.

Copyright $\odot$ 2016, Turkish Society for Radiation Oncology

\section{Introduction}

Aloe vera, sometimes also known as Aloe barbadensis or Aloe capensis, is a cactus-like perennial plant with fleshy leaves that belongs to the family Asphodelaceae. The Aloe vera plant has been used in folk medicine for thousands of years, dating back to the times of ancient Egypt. Of South African origin, Aloe vera was introduced to China and southern European countries in the $17^{\text {th }}$ century. $[1,2]$ It also has an important place in the field of traditional medicine in some modern cultures, such as China, Japan, and India.[3] In the United States, Aloe vera first gained popularity in the 1930s, as a consequence of studies indicating efficacy in treating X-ray burns.[4,5]

Aloe vera has commonly been used in the treatment of skin problems. Aloe vera products for topical use are derived from a clear, viscous liquid that appears when the leaves of the plant are cut, and this liquid is frequently an ingredient in cosmetics and alternative medicine products. $[6,7]$ These products are claimed to be effective in the treatment of many dermal and mucosal problems such as wounds, burns, frostbite, xerosis, psoriasis, eczema, genital herpes, aphthous stomatitis, and seborrheic dermatitis.[8,9] However, studies have not found adequate evidence to support claims of effectiveness of Aloe vera treatment. Although some studies have demonstrated promising results in treating burns and abrasions in particular, they have not proven Aloe vera to be superior to standard treatment for these conditions. [10,11] Aloe vera products for oral consumption include capsules made of Aloe leaves, dried latex, and Aloe vera juice.[6] These products are utilized especially in the treatment of constipation because of a laxative effect. However, the US Food and Drug Administration (FDA) has stated that use of aloe as a laxative is not safe. Moreover, the FDA required aloe laxative products to be removed from all sales 
points in the United States in 2002.[10,12] In recent years, Aloe vera has frequently been claimed to have an effect on cancer. In particular, topical use is alleged to be effective in the prevention and treatment of skin irritation after radiotherapy; however, clinical studies do not support these claims. $[8,13-16]$

\section{Laboratory Studies on the Effects of Aloe Vera on Cancer}

In laboratory studies, Aloe vera has been shown to have some anti-oxidant, anti-inflammatory, immunomodulatory, and anti-cancer properties.[17-19] The immunomodulatory properties of Aloe vera, which contains many active components, are attributed to acemannan, while its anti-proliferative properties are attributed to the components anthracene and anthraquinone.[20,21]

In a study published in 2014, Aloe emodin, an anthraquinone component in Aloe vera, inhibited the proliferation and increased the radiosensitivity of HeLa cervical cancer cell lines.[22] In a laboratory study on hepatocellular cancer cell lines, it also inhibited cell proliferation and induced cell apoptosis.[23] In a study on breast cancer cell lines, it once again suppressed proliferation, [24] and in another study on colon cancer cell lines, it induced apoptosis through the activation of caspase-6.[25] Similarly, there are also studies showing that Aloe emodin inhibited cell growth in cell lines of lung cancer, leukemia, and neuroectodermal cancer.[26-28] In another study, Aloin, another anthraquinone component in aloe, inhibited angiogenesis through suppression of vascular endothelial growth factor (VEGF).[29] In an in vitro study carried out on neuroblastoma cells, Aloe vera was found to decrease neuroblastoma cell proliferation by suppressing cyclin D2 transcription.[30] In a study on prostate cancer cell cultures (PC3), Aloe emodin was found to inhibit prostate cancer cell proliferation by acting through mammalian target of rapamycin complex 2 (mTORC2) (Table 1).[31]

\section{Clinical Studies on the Effects of Aloe Vera on Cancer}

Despite some positive results obtained from a few studies on the anti-cancer potential of Aloe vera, such results are not adequate to be reflected in clinical practice. The most highlighted and advocated effect of Aloe vera is the prevention and treatment of skin irritation caused by radiotherapy.[32] Clinical studies have produced inconsistent results and have not verified this effect. In a Phase III study carried out on 225 breast cancer patients treated with postoperative adjuvant radiotherapy, it was stated that Aloe vera provided no significant benefit to skin problems caused by radiotherapy.[13] Another study combining 2 separate Phase III randomized clinical studies had similar findings regarding the effect of Aloe vera.[14] Comparable results were also obtained in a review compilation of 7 clinical studies.[15] In another study that enrolled 57 patients with head and neck cancer, Aloe vera was observed to delay the onset of radiotherapy-induced skin lesions and reduce their intensity; however, it was ineffective in the prevention of lesions or reducing their incidence.[16]

In a study that involved the evaluation of the use of Aloe vera in conjunction with chemotherapy, a subset of 240 patients with metastatic tumor was given chemotherapy alone, while the rest also received $10 \mathrm{mg}$ daily oral dose of Aloe vera. Tumor regression rate and 3-year survival rate were found to be significantly higher in the group given chemotherapy plus Aloe vera.[20] In a small epidemiological study, lung cancer incidence was observed to be lower in those using Aloe vera orally on a regular basis; however, the study was not of a level that results might be considered promising.[33]

In a systematic compilation published in 2011, the prevention of oral mucositis due to chemotherapy by using Aloe vera was studied. Despite some positive results, researchers noted that this effect might be specific to a certain chemotherapeutic agent or type of cancer and emphasized the need for well-designed studies with subgroup analyses.[34] In a preliminary study carried out on 20 patients with oral submucous fibrosis, Aloe vera gel provided a benefit in reducing the symptoms.[35] In another study that enrolled 58 patients with head and neck cancer, the oral administration of Aloe vera made no contribution in terms of reducing symptoms or increasing quality of life (Table 1).[36]

\section{Potential Side Effects of Aloe Vera}

Although many proponents of alternative medicine claim that Aloe vera has no side effects, it is an herbal treatment about which many toxicity cases have been reported.[37] Moreover, Aloe vera administered by injection resulted in death in 4 reported cases. $[38,39]$

In a case reported in the literature, a 56-year-old female patient with reticular lichen planus lesion in her mouth declined use of corticosteroid and turned to alternative medicine procedures that included the 
Table 1 Selected laboratory and clinical studies

\begin{tabular}{|c|c|c|c|}
\hline Reference & Type of study & Type of cancer & Result \\
\hline Luo J et al.[22] & Laboratory & Cervical cancer & Increased radiosentivity \\
\hline Kuo PL et al.[23] & Laboratory & Hepatocellular cancer & $\begin{array}{l}\text { - Inhibited the cell proliferation } \\
\text { - Induced the cell apoptosis }\end{array}$ \\
\hline Huang PH et al.[24] & Laboratory & Breast cancer & Suppressed the proliferation \\
\hline Suboj P et al.[25] & Laboratory & Colon cancer & Induced apoptosis \\
\hline Lee HZ et al.[26] & Laboratory & Lung carcinoma & Inhibited cell growth in cell lines \\
\hline Chen HC et al.[27] & Laboratory & Promyelocytic leukemia & Inhibited cell growth in cell lines \\
\hline Pecere T et al.[28] & Laboratory & Neuroectodermal tumors & Inhibited cell growth in cell lines \\
\hline Pan Q et al.[29] & Laboratory & Colorektal cancer & $\begin{array}{l}\text { Inhibited the angiogenesis through VEGF } \\
\text { suppression }\end{array}$ \\
\hline Yonehara A et al.[30] & Laboratory & Neuroblastoma & Suppressing the cyclin D2 transcription level \\
\hline Liu K et al.[31] & Laboratory & Prostate cancer & $\begin{array}{l}\text { Inhibit cancer cell proliferation by acting through } \\
\text { mammalian target of rapamycin complex } 2\end{array}$ \\
\hline Heggie S et al.[13] & Clinical & Breast cancer & $\begin{array}{l}\text { No significant benefit in skin problems caused by } \\
\text { radiotherapy }\end{array}$ \\
\hline Williams MS et al.[14] & Clinical & 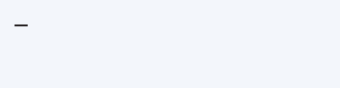 & $\begin{array}{l}\text { No significant benefit in skin problems caused by } \\
\text { radiotherapy }\end{array}$ \\
\hline George J et al.[16] & Clinical & Head and neck cancer & $\begin{array}{l}\text { Delay the start time of radiotherapy induced skin } \\
\text { lesions and reduce their intensity }\end{array}$ \\
\hline Lissoni P et al.[20] & Clinical & Metastatic cancers & Tumor regression \\
\hline Su CK et al.[36] & Clinical & Head and neck cancer & $\begin{array}{l}\text { No contribution in terms of reducing the symptoms } \\
\text { and increasing quality of life }\end{array}$ \\
\hline
\end{tabular}

consumption of Aloe vera juice. Although she used this product for a period of 11 months, there was no improvement in oral lichen planus, and in fact, hypothyroidism developed as well.[40] In another case where Aloe vera was used in conjunction with chemotherapy, serious hypokalemia developed.[41] In a study published in 2010, 3 cases of toxic hepatitis due to use of Aloe vera were reported.[42] There are many other cases of toxic hepatitis associated with Aloe vera reported in the literature.[43,44] There are also cases in which it delayed recovery of postoperative wounds, [45] and caused the development of Henoch-Schonlein purpura.[46]

Abdominal cramps, diarrhea and related electrolyte disorders due to the oral administration of Aloe vera have been reported. In some preliminary studies, Aloe vera was stated to have a blood sugar reducing effect, and diabetic patients using or considering using Aloe vera were warned about the risk of possible hyperglycemia. The National Center for Complementary and Integrative Health (NCCIH) states that there is not adequate scientific evidence supporting the use of Aloe vera for any health problem.[10]

In a study conducted by the US National Toxicology Program (NTP), the carcinogenic potential of the oral administration of Aloe vera in mice was investigated.
The results indicated that long-term exposure to Aloe vera might be carcinogenic.[47] Another study carried out on mice showed that Aloe vera taken orally is likely to trigger colon cancer; [48] and another study showed that Aloe vera may increase skin cancer induced by ultraviolet rays.[49]

In the literature, there is also evidence regarding drug interactions with Aloe vera. A laboratory study showed that the plant juice of Aloe vera inhibits the CYP3A4 and CYP2D6 enzymes which may affect the intracellular concentration of drugs metabolized by these enzymes. [50] It has been stated that use of Aloe vera might increase the effects of antiarrhythmics, cardiac glycosides, diuretics, and steroid drugs.[32] In 1 instance, a possible sevoflurane-Aloe vera interaction may be responsible for a women losing approximately 5 liters of blood during surgery.[51]

\section{Conclusion}

Aloe vera is a product likely to have certain benefits because of the active components in its content; however, its superiority to standard treatments for any health problem has yet to be shown unequivocally. It is claimed to be effective in a variety of applications, but it is potential effect on cancer has been of particular 
interest in recent years. The most advocated benefit of Aloe vera for a cancer patient is its alleged ability to prevent and treat skin lesions caused by radiotherapy. However, clinical studies carried out indicate that Aloe vera is ineffective in this regard. On the other hand, some laboratory studies have indicated certain effects of oral and injected Aloe vera products; however, these results have not been verified in clinical studies. Many side effects as well as related deaths have been reported in the literature. For now, it would be practical to abstain from using these products until a clear benefit of Aloe vera and its active components is demonstrated and a safety profile for use is introduced.

\section{Conflict of interest: None declared.}

\section{References}

1. Farooqi AA, Sreeramu BS. Cultivation of medicinal and aromatic crops. Orient Longman, India. 2001.

2. Reynolds T, Dweck AC. Aloe vera leaf gel: a review update. J Ethnopharmacol 1999;68(1-3):3-37.

3. Foster M, Hunter D, Samman S. Evaluation of the nutritional and metabolic effects of Aloe vera. In: Benzie IFF, Wachtel-Galor S, editors. Source herbal medicine: biomolecular and clinical aspects. 2nd ed. Boca Raton (FL): CRC Press/Taylor \& Francis; 2011.

4. Collins EE, Collins C. Roentgen dermatitis treated with fresh whole leaf of aloe vera. Am J Roentgenol 1935;33:396-7.

5. Wright CS. Aloe vera in the treatment of roentgen ulcers and telangiectasis. J Am Med Assoc 1935;106:1363-4.

6. Ernst E, Pittler MH, Wider B, Boddy K. The desktop guide to complementary and alternative medicine. 2nd ed. Edinburgh: Elsevier Mosby; 2006.

7. Boudreau MD, Beland FA. An evaluation of the biological and toxicological properties of Aloe barbadensis (miller), Aloe vera. J Environ Sci Health C Environ Carcinog Ecotoxicol Rev 2006;24(1):103-54.

8. Hossain MS, Mamun-Or-Rashid ANM, Towfique NM, Sen MK. A review on ethnopharmacological potential of Aloe vera L. J Intercult Ethnopharmacol 2013;2:113-20.

9. Serrano M, Valverde JM, Guillén F, Castillo S, Martínez-Romero D, Valero D. Use of Aloe vera gel coating preserves the functional properties of table grapes. J Agric Food Chem 2006;54(11):3882-6.

10. National Center for Complementary and Alternative Medicine. "Aloe Vera - Side Effects and Cautions". https://nccih.nih.gov/health/aloevera\#cautions Retrieved 2011;10-7.
11. Feily A, Namazi MR. Aloe vera in dermatology: a brief review. G Ital Dermatol Venereol 2009;144(1):85-91.

12. Food and Drug Administration. Status of Certain Additional Over-the-Counter Drug Category II and III Active Ingredients. http://www.fda.gov/ohrms/ dockets/98fr/050902a.htm. Accessed November 26, 2014.

13. Heggie S, Bryant GP, Tripcony L, Keller J, Rose P, Glendenning M, Heath J. A Phase III study on the efficacy of topical aloe vera gel on irradiated breast tissue. Cancer Nurs 2002;25:442-51.

14. Williams MS, Burk M, Loprinzi CL, Hill M, Schomberg PJ, Nearhood K, et al. Phase III double-blind evaluation of an aloe vera gel as a prophylactic agent for radiation-induced skin toxicity. Int J Radiat Oncol Biol Phys 1996;36(2):345-9.

15. Richardson J, Smith JE, McIntyre M, Thomas R, Pilkington $\mathrm{K}$. Aloe vera for preventing radiation-induced skin reactions: a systematic literature review. Clin Oncol (R Coll Radiol) 2005;17(6):478-84.

16. George J. To assess the effectiveness of aloe vera gel in preventing skin reactions associated with radiotherapy. Indian Journal of Palliative Care 2011;17:91-103.

17. Yagi A, Kabash A, Okamura N, Haraguchi H, Moustafa SM, Khalifa TI. Antioxidant, free radical scavenging and anti-inflammatory effects of aloesin derivatives in Aloe vera. Planta Med 2002;68(11):957-60.

18. Pugh N, Ross SA, ElSohly MA, Pasco DS. Characterization of Aloeride, a new high-molecular-weight polysaccharide from Aloe vera with potent immunostimulatory activity. J Agric Food Chem 2001;49(2):1030-4.

19. Lee KH, Kim JH, Lim DS, Kim CH. Anti-leukaemic and anti-mutagenic effects of di(2-ethylhexyl)phthalate isolated from Aloe vera Linne. J Pharm Pharmacol 2000;52(5):593-8.

20. Lissoni P, Rovelli F, Brivio F, Zago R, Colciago M, Messina $G$, et al. A randomized study of chemotherapy versus biochemotherapy with chemotherapy plus Aloe arborescens in patients with metastatic cancer. In Vivo 2009;23(1):171-5.

21. Shelton RM. Aloe vera. Its chemical and therapeutic properties. Int J Dermatol 1991;30(10):679-83.

22. Luo J, Yuan Y, Chang P, Li D, Liu Z, Qu Y. Combination of aloe-emodin with radiation enhances radiation effects and improves differentiation in human cervical cancer cells. Mol Med Rep 2014;10(2):731-6.

23. Kuo PL, Lin TC, Lin CC. The antiproliferative activity of aloe-emodin is through p53-dependent and p21dependent apoptotic pathway in human hepatoma cell lines. Life Sci 2002;71(16):1879-92.

24. Huang PH, Huang CY, Chen MC, Lee YT, Yue CH, Wang HY, et al. Emodin and Aloe-Emodin Sup- 
press Breast Cancer Cell Proliferation through ER a Inhibition. Evid Based Complement Alternat Med 2013;2013:376123.

25. Suboj P, Babykutty S, Srinivas P, Gopala S. Aloe emodin induces G2/M cell cycle arrest and apoptosis via activation of caspase- 6 in human colon cancer cells. Pharmacology 2012;89(1-2):91-8.

26. Lee HZ, Hsu SL, Liu MC, Wu CH. Effects and mechanisms of aloe-emodin on cell death in human lung squamous cell carcinoma. Eur J Pharmacol 2001;431(3):287-95.

27. Chen HC, Hsieh WT, Chang WC, Chung JG. Aloeemodin induced in vitro G2/M arrest of cell cycle in human promyelocytic leukemia HL-60 cells. Food Chem Toxicol 2004;42(8):1251-7.

28. Pecere T, Gazzola MV, Mucignat C, Parolin C, Vecchia FD, Cavaggioni A, et al. Aloe-emodin is a new type of anticancer agent with selective activity against neuroectodermal tumors. Cancer Res 2000;60(11):2800-4.

29. Pan Q, Pan H, Lou H, Xu Y, Tian L. Inhibition of the angiogenesis and growth of Aloin in human colorectal cancer in vitro and in vivo. Cancer Cell Int 2013;13(1):69.

30. Yonehara A, Tanaka Y, Kulkeaw K, Era T, Nakanishi Y, Sugiyama D. Aloe vera Extract Suppresses Proliferation of Neuroblastoma Cells In Vitro. Anticancer Res 2015;35(8):4479-85.

31. Liu K, Park C, Li S, Lee KW, Liu H, He L, et al. Aloeemodin suppresses prostate cancer by targeting the mTOR complex 2. Carcinogenesis 2012;33(7):1406-11.

32. Ulbricht C, Armstrong J, Basch E, Basch S, Bent S, Dacey $C$, et al. An evidence-based systematic review of Aloe vera by the natural standard research collaboration. J Herb Pharmacother 2007;7(3-4):279-323.

33. Sakai R. Epidemiologic survey on lung cancer with respect to cigarette smoking and plant diet. Jpn J Cancer Res 1989;80(6):513-20.

34. Worthington HV, Clarkson JE, Bryan G, Furness S, Glenny AM, Littlewood A, et al. Interventions for preventing oral mucositis for patients with cancer receiving treatment. Cochrane Database Syst Rev 2011;(4):CD000978.

35. Sudarshan R, Annigeri RG, Sree Vijayabala G. Aloe vera in the treatment for oral submucous fibrosis - a preliminary study. J Oral Pathol Med 2012;41(10):75561.

36. Su CK, Mehta V, Ravikumar L, Shah R, Pinto H, Halpern J, et al. Phase II double-blind randomized study comparing oral aloe vera versus placebo to prevent radiation-related mucositis in patients with headand-neck neoplasms. Int J Radiat Oncol Biol Phys 2004;60(1):171-7.
37. Palmer ME, Haller C, McKinney PE, Klein-Schwartz W, Tschirgi A, Smolinske SC, et al. Adverse events associated with dietary supplements: an observational study. Lancet 2003;361(9352):101-6.

38. Anonymous. MD Loses license after injecting aloe kills 3. Vol 20. Peabody, MA: National Council Against Health Fraud; 1997:4.

39. Anonymous. License revoked for aloe vera use. Nat Med Law 1998;1:1-2.

40. Pigatto PD, Guzzi G. Aloe linked to thyroid dysfunction. Arch Med Res 2005;36(5):608.

41. Baretta Z, Ghiotto C, Marino D, Jirillo A. Aloe-induced hypokalemia in a patient with breast cancer during chemotherapy. Ann Oncol 2009;20(8):1445-6.

42. Yang HN, Kim DJ, Kim YM, Kim BH, Sohn KM, Choi MJ, et al. Aloe-induced toxic hepatitis. J Korean Med Sci 2010;25(3):492-5.

43. Rabe C, Musch A, Schirmacher P, Kruis W, Hoffmann R. Acute hepatitis induced by an Aloe vera preparation: a case report. World J Gastroenterol 2005;11(2):303-4.

44. Lee J, Lee MS, Nam KW. Acute toxic hepatitis caused by an aloe vera preparation in a young patient: a case report with a literature review. Korean J Gastroenterol 2014;64(1):54-8.

45. Schmidt JM, Greenspoon JS. Aloe vera dermal wound gel is associated with a delay in wound healing. Obstet Gynecol 1991;78(1):115-7.

46. Kim EJ, Kim HJ, Kim SG, Lee YS, Oh JE, Seo JW, et al. Aloe-induced Henoch-Schonlein purpura. Nephrology (Carlton) 2007;12(1):109.

47. Boudreau MD, Beland FA, Nichols JA, Pogribna M. Toxicology and carcinogenesis studies of a nondecolorized [corrected] whole leaf extract of Aloe barbadensis Miller (Aloe vera) in F344/N rats and B6C3F1 mice (drinking water study). Natl Toxicol Program Tech Rep Ser 2013;(577):1-266.

48. Yokohira M, Matsuda Y, Suzuki S, Hosokawa K, Yamakawa K, Hashimoto N, et al. Equivocal colonic carcinogenicity of Aloe arborescens Miller var. natalensis berger at high-dose level in a Wistar Hannover rat 2-y study. J Food Sci 2009;74(2):T24-30.

49. National Toxicology Program. Toxicology and carcinogenesis studies of 3,3',4,4'-tetrachloroazobenzene (TCAB) (CAS No. 14047-09-7) in Harlan SpragueDawley rats and B6C3F1 mice (gavage studies). Natl Toxicol Program Tech Rep Ser 2010;(558):1-206.

50. Djuv A, Nilsen OG. Aloe vera juice: $\mathrm{IC}_{50}$ and dual mechanistic inhibition of CYP3A4 and CYP2D6. Phytother Res 2012;26(3):445-51.

51. Lee A, Chui PT, Aun CS, Gin T, Lau AS. Possible interaction between sevoflurane and Aloe vera. Ann Pharmacother 2004;38(10):1651-4. 